\title{
Exploring the Application of Islamic Legal Maxims in Advertising: Practices of manufacturers
}

\author{
Nurzahidah Jaapar, Mohd Faiz Mohamed Yusof, \\ Mohd Dani Mohd, Sharifah Fadylawaty Syed Abdullah \\ Academy of Contemporary Islamic Studies (ACIS), \\ Universiti Teknologi MARA Shah Alam, 40450 Shah Alam, Selangor Malaysia, \\ nurzah8883@uitm.edu.my, faizyusof@uitm.edu.my, mdani393@uitm.edu.my, fadywaty4935@uitm.edu.my, \\ Tel of 1st Author:
}

\begin{abstract}
The previous study has argued that the focus of advertising has caused many socio-economic hazards in damaging moral and cultural values by causing exploitation and fraud. Engaging in a systematic content analysis procedure, this article aims to explore the applications of Islamic Legal Maxims in advertising with regards to the manufacturers' practices in supplementary food products industries. Next, explicit purposes are to determine the malpractices among manufacturers in their advertising as well as a shariah-compliant parameter as a guideline to manufacturers in advertising supplementary food products based on the integration of Islamic Legal Maxim and principles of Shariah.
\end{abstract}

Keywords: Advertising, supplementary food, Islamic Legal maxim

eISSN: 2398-42870 2021. The Authors. Published for AMER ABRA CE-Bs by e-International Publishing House, Ltd., UK. This is an open access article under the CC BYNC-ND license (http://creativecommons.org/licenses/by-nc-nd/4.0). Peer-review under responsibility of AMER (Association of Malaysian Environment-Behaviour Researchers), ABRA (Association of Behavioural Researchers on Asians/Africans/Arabians) and CE-Bs (Centre for Environment-Behaviour Studies), Faculty of Architecture, Planning \& Surveying, Universiti Teknologi MARA, Malaysia.

DOI: https://doi.org/10.21834/ebpj.v6iSI5.2942

\subsection{Introduction}

Historically, the advertising industry in Malaysia and Singapore began in the 19th century with the emergence of international agencies such as the United States, Japan, and the United Kingdom (Abdullah \& Ph, 2002; Rahim, M. H. A. 1996). Malaysia is expected to increase to the next marketing level, which offers digital advertisements through substantial and extensive support from the government which has been allocating RM210 million for the year 2019 until 2021 in the services sector to boost the efficient transition to industrial technology 4.0 (MOF, 2020; Ardhityo, 2019). Through this medium, the government has provided rapid telecommunications facilities with a significant saving of fifty percent for current advertising costs compared to conventional advertising (Andreas \& Halina, 2016). This trend provided a strategic approach for the business entity and contributed significantly to the national economic development agenda (Serimah Mohd Sallehuddin 2020). The opinion was supported by the data of MCMC (2020), the government through PENJANA 2020 has injected gigantic investment into the digital economy of RM1.8 billion and RM 190 million for the creative industry including the advertising industry to promote innovation and economic evolution through digital platforms (PWC, 2019). According to Meyer, SB, Shnir, F., Simeonov, S., Kozek, E., O'malley, C., \& Jaye, D, (2016), digital advertising is said to be a significant source of revenue for online service providers, web services, and internet getaways. Hence, the Industrial revolution 4.0 developed for the industry transformation through intelligent networking with the help of communication technology to achieve improvement for effectiveness and efficiency in the business activities.

According to Ullah, Najeeb \& Hussain, Mustansar, (2015), advertising is one of the most integral parts of a business entity that integrates several key fields, including marketing, communications, consumerism, economics, education, social and religious affairs

eISSN: 2398-4287@ 2021. The Authors. Published for AMER ABRA cE-Bs by e-International Publishing House, Ltd., UK. This is an open access article under the CC BYNC-ND license (http://creativecommons.org/licenses/by-nc-nd/4.0/). Peer-review under responsibility of AMER (Association of Malaysian Environment-Behaviour Researchers), ABRA (Association of Behavioural Researchers on Asians/Africans/Arabians) and cE-Bs (Centre for Environment-Behaviour Studies), Faculty of Architecture, Planning \& Surveying, Universiti Teknologi MARA, Malaysia.

DOI: https://doi.org/10.21834/ebpj.v6iSl5.2942 
(Kamassi, A.,2019, Abdullah, Kalthom \& Haque, Ahasanul \& Ahmed, Faruk \& Shafiq, Ali., 2019; Shafiq, A., Haque, A., \& Abdullah, K., 2016). It has different objectives beyond its practice; to inform, educate, convince, persuade, remind, offer, and profit (Safira, Anya, 2017; Busen \& Mustaffa, 2014). Advertising consequently plays a significant role in people's lifestyle habits and expectations. Mass media, particularly digital platforms; TV and internet ads, have had a considerable impact on people's adoption of a healthy lifestyle as confirmed in various studies (Etemad K, Ebrahimi P, Azimi H, Lotfi M, Nojomi M. A., 2016; Huang L, Mehta K, Wong M., 2011). However, the survival of the current market is severe because large numbers of manufactures compete with various kinds of products and services (Hassali, Mohamed \& Shakeel, Sadia., 2020). An effective strategy in product positioning can improve business sales (Ertemel, Adnan Veysel \& Ammoura, Ahmad, 2019). Hence, the application of advertising is used as a promoting tool to introduce and encourage potential consumers in purchasing the products and brands choose by the manufacturers nowadays. Nevertheless, the advertisement used by the manufacturers to compete with other competitors is commonly unethical and sensitive by delivering false information, overclaimed, mispresented of the product that can affect consumer protection towards their rights (Aziz, Azmin \& Md Rahin, Nurliana \& Asri, Norhazwani. 2019).

While Islam is a comprehensive religion relay on a message that fosters the right way of life. The Islamic practice of advertising the supplementary food product suggests that the source mechanism and actors should comply with Islamic principles (Abdullah, Kalthom \& Haque, Ahasanul \& Ahmed, Faruk \& Shafiq, Ali, 2019). The central aspect of halal advertising is quality and safety, which attracts many consumers and increases the demand in the market (Yarar, Ali. 2020). The previous study has argued that the focus of advertising has caused many socio-economic hazards in damaging moral and cultural values by causing exploitation and fraud, as well as general dissatisfaction with products while delivering little added value are some of its common criticism due to malpractices of the manufacturers (Rasit, Rosmawati \& Hanin Hamjah, Salasiah \& Misrom, Azimah \& Yahya, Nur Hikmah., 2019). However, there is a limited study conducted by previous researchers on the Islamic legal maxim perspective in this area. Therefore, the objectives of this paper are as follows:

a. To explore the application of the Islamic Legal Maxims in advertising a supplementary food product

b. To determine the malpractices issues conducted by the manufacturers in advertising supplementary food products from the perspective of Islamic legal maxims.

c. To propose the shariah-compliant parameters a guideline for manufacturers in advertising supplementary food products based on the integration of Islamic Legal Maxim and parameters of Shariah.

\subsection{Literature Review}

\subsection{The Application of Islamic Legal Maxims in advertising}

Islamic Legal maxim generally known as al-qawaid fighiyyah comes as principles of Islamic law (Laldin, 2014). Al-Zarqa defined alqawaid fiqhiyyah as "the general figh principles which are presented in a simple format consisting of the general rules of shariah in a particular field related to it" (al-Zarqa, 2007). They are applied in various cases that come under common rulings such as business transactions, manufacturing, marketing, advertising, communication, social media, and more (Rahman, Md. Habibur, 2015). The existence of al-qawaid fighiyyah also implicitly rebuts those who accuse Islamic law of being inflexible and inert, yet they enable the jurist to determine the rulings for newly arising matters by referring them to the relevant maxims (Kamali, M.H. (2012). Due to versatility and wide-ranging articulation, Islamic legal maxims tend to encapsulate the broader concepts and precepts of Islamic jurisprudence. More importantly, they can help one in arriving at the appropriate ruling where no explicit law exists (Mohamad Yunus, Mohamad Ismail 2019; Rahman, Md. Habibur. (2015).

Fundamentally, in the context of advertising food supplementary food, the advertising opportunity is created tremendously as reported by the PIKOM, the consumer nowadays spends more on the food, health, personal care, fashion, and beauty product as supported by the data below:

Table 1: The Income Statistics and Expenditure Categories in E-Commerce by Category In 2019

\begin{tabular}{|l|c|}
\hline \multicolumn{1}{|c|}{ Category } & Value (RM) (million) \\
\hline Fashion and beauty & 770.1 \\
\hline Food and personal care product & 483 \\
\hline Furniture and appliances & 553 \\
\hline
\end{tabular}

Source: Malaysian Computer and Multimedia Industry Association (PIKOM), E-commerce in Malaysia, (https://datareportal.com/)

Consequently, the issues of advertising occur when the advertiser promotes unqualified, prohibited, fake, default products (Mokhtar, A. (2019). Plus, unethical advertising contains the subliminal message, comparison advertisement, harmful content, scam advertising, exploitation of name, imitation advertising, and non-availability of the advertised product (Marhaeni, D., 2020). It is even more frustrating when advertisers use an ad in the wrong way, especially for the advertisement of a supplementary food product that does not comply with Muslim consumer rights, because it deceives and risks public protection as well as overclaim (Aziz et.al, 2019). Due to these issues, the shariah basis in advertising needs to be redefined (Ahmad, A. A., \& Suhardi, S. S., 2018). Through the legal maxims of Islamic Law, the general principles of shariah-compliant advertising could portray the goals and objectives of the shariah (al-Suyuti, Jalal al-Din 'Abd Rahman ibn Abi Bakr ibn Muhammad, 1983). The Muslim jurists approve that knowledge of al-qawaid fighiyyah is an important requisite for properly understanding the Shariah, besides to provides the easiest means for the non-specialist in shariah such as the 
manufacturers as well as advertisers to become acquainted with figh and its comprehensiveness as Islam always guide everything that we do in making sure that all the activities give benefit to the consumer (al-Suyuti, 1983).

The word 'al-qawaid' is the plural of al-qaidah, which means principles, and figh means Islamic law; therefore, generally, Qawaid Fiqhiyyah means the principles of Islamic law (Laldin, 2014). Al-Zarqa defined Qawaid Fiqhiyyah as "the general fiqh principles which are presented in a simple format consisting of the general rules of Sharī 'ah in a particular fieldrelated to it" (al-Zarqa, 2007). Indeed, Qawaid Fiqhiyyah or legal maxims of Islamic Law are the general rules of figh that portray the goals and objectives of the Sharī ah. They are applied in various cases that come under the common rulings such as transactions, marriage, and crimes and play a very an important role in deducing many rules of figh since they provide a guideline to come up with particular hukm. The word 'al-qawaid' is the plural of al-qaidah, which means principles, and figh means Islamic law; therefore, generally, Qawaid Fiqhiyyah means the principles of Islamic law (Laldin, 2014). Al-Zarqa defined Qawaid Fiqhiyyah as "the general figh principles which are presented in a simple format consisting of the general rules of Sharī 'ah in a particular field related to it” (al-Zarqa, 2007). Indeed, Qawaid Fiqhiyyah or legal maxims of Islamic Law are the general rules of fiqh that portray the goals and objectives of the Sharī ah. They are applied in various cases that come under the common rulings such as transactions, marriage, and crimes and play a very an important role in deducing many rules of figh since they provide a guideline to come up with particular hukm.

\subsection{Supplementary food advertising concept according}

According to the Food and Drug Administration (FDA), supplemental foods known as dietary substitutes are manufactured products intended to supplement the diet when taken by mouth as a pill, capsule, tablet, or liquid. A supplement may supply nutrients either extracted from food sources or synthetic, either individually or in combination, to increase their consumption (FDA, 2021). At the same time, the National Pharmaceutical Regulatory Agency, the Ministry of Health (NPRA), Health Supplement (HS), means any product that is used to supplement the diet and to maintain, enhance and improve the health of the human body. It is presented in small unit dosage forms such as capsules, tablets, powders, liquids, and does not include any sterile preparations (NPRA, 2021). To date, by selling different products on the digital platform, regardless of the platform, such daily care product, medicine, cosmetics, food, technology, and more that have provided a wide range of consumer options and selections. In Malaysia, to monitor a huge industry of advertisement, certain laws were developed to govern the activity in advertising. It is important to note that, no specific action was a codified advertisement in Malaysia. Advertisers are under an obligation, to tell the truth, imposed to the audience as instruct by Malaysia act in advertising According to the Communications and Multimedia Act 1998, section 256 (3) \& Medicines (Advertisement Act 1956) section 6.

Therefore, the manufacturers are legally obliged to state the fact of the product information to the audience (Koorosh Etemad et.al, 2016). The information whether wholly or partly is for the audience to know about the characteristics and conditions of the product before making a response in purchase the product (Nanda, A. A. G. S., \& Sukranatha, A. A. K., 2019). The guidelines from the Malaysian Code of Advertising Practice (ASA) emphasize the necessity in speaking the truth to avoid the importance of speaking the truth and not take for granted consumers' lack of experience or knowledge as mention under section II (2) (Trade Description Act, 2011). The code practice state that the advertisement should not frame the audience, purposely or intentionally in not display accurate information to the deceived audience especially those who are lack knowledge and experience (ASA, 2008).

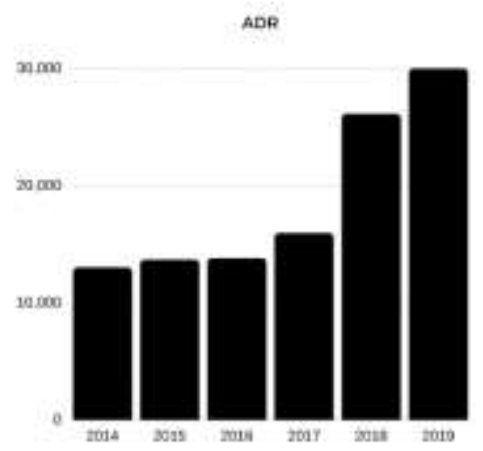

Table 2: Total report of ADR (Adverse Drug Reaction) from the year 2014-2019

However, it is found that advertising is charged with all sorts of negative effects includes promoting unsafe and harmful products, wasteful spending, and exploiting women and kids (Mokhtar, A. 2019; NPRA, 2019). According to Aziz et.al (2019), found that shariahcompliant advertising for health and beauty food products on the Facebook platform has become an effective marketing trend and method. However, the statement by O'Donoghue, A. C., Boudewyns, V., Aikin, K. J., Geisen, E., Betts, K. R., \& Southwell, B. G. (2016), clarifies that awareness of unethical advertisements about health and personal care products are still low. Besides, there are many issues involved in compromising consumer rights, such as pharmaceuticals and nutraceutical products containing restricted substances 
(Nor Afzan Mohamad Yusof (2019). As a result, several reported cases with unsafe ingredients have been reported to the health supplement industry as follows:

\begin{tabular}{l|c|c|c|c|c}
\hline \multicolumn{1}{c|}{ Year/Category } & 2015 & 2016 & 2017 & 2018 & 2019 \\
\hline $\begin{array}{l}\text { Pharmaceutical } \\
\text { product }\end{array}$ & 793 & 613 & 838 & 991 & 893 \\
\hline${ }^{*}$ TMHS product & 11 & 6 & 3 & 22 & 236 \\
\hline \multicolumn{7}{r}{$\begin{array}{l}\text { *Traditional Medicines Health Supplement } \\
\text { Source: National Pharmaceutical Regulatory Agency, MOH (2019) }\end{array}$}
\end{tabular}

According to the NPRA Guidelines on Advertising Medicines and Medical Products to the General Public (NPRA, 2019), a list of offences involving new food companies is prohibited from placing on the market and advertising any claims, either directly or indirectly, relating to the prevention, treatment, alleviation, cure or diagnosis of diseases and conditions such as diseases or defects. Next, the advertisement should not contain any acts of violence, illegal, criminal activity, or appear to condone any such acts as cyberbully and body shaming (Akbar, F., \& Safira, A., 2017). Advertisements should not, without justification, show or refer to dangerous practices or manifest a level of regard for safety (Akta Ubat Iklan \& Jualan 1956). Particular attention should be paid to advertising directed at or depicting children or young people. Publicity of health products is also prohibited by tampering with Malaysian standards of morality or deception, defamation, and degradation of other products on the market, misleading statements, and justification by exploiting ignorance and public excitement by including unverifiable scientific data. Subsequently, advertising is prohibited from building confidence that intimidates or distorts users, misuses the JAKIM halal logo, posts LUI (Lembaga Iklan Ubat, 1976) approved ads along with products that do not require the LUI approval to avoid public confusion. While advertising on the Internet, such as the website, should not contain information about nature and content to health professionals, it should be restricted and clearly labelled for use by health professionals.

The NPRA ads guideline maintains a high level of social responsibility for consumers and society to explain what is 'socially responsible' advertising practices such as celebrity endorsement, impressions of professional advice, user testimonials, claims and evidence, tests, trials and research references, comparative advertising, encouragement of undesirable behaviour (Garis Panduan kepada Industri dalam Pengiklanan Produk Kesihatan, NPRA). In the therapeutic claims section, the ads should not contain any words, phrases, or illustrations in advertisements that claim or imply the healing of any illness other than the relief of its symptoms, unless approved by the Medical Advisory Board (MAB) (pharmacy.gov). In the case of an advertisement for a medicinal product, no specific reference shall be made to the specific properties of any individual ingredient unless a recommendation of this nature has been approved by the Drug Control Authority (DCA) (NPRA, 2021), for inclusion in the package insert of the medicinal product (NPRA, 2019). This study was, therefore, undertaken to explore the applications of Islamic Legal Maxims in advertising with regards to the manufacturers' practices in supplementary food products industries in order determine to malpractices among manufacturers in their advertising as well as to propose the shariah-compliant parameter as a guideline to manufacturers in advertising supplementary food products based on the integration of Islamic Legal Maxim and principles of shariah.

\subsection{Methodology}

This paper adopts a qualitative approach to research using library research. Empirically, this research is based on the case reported in the marketing of supplementary food products. This qualitative study reports on the thematic content analysis method based on the Quranic approach and the Islamic Legal Maxims; and other related resources, such as journal articles, legal reports and historical reports, to achieve the research objective. The sampling was selected using purposive sampling as the researcher identify these products are among the most issues complained about and reported by the consumers.

\subsection{Result and Discussion}

\subsection{Application of the Islamic Legal Maxims in advertising}


Table 3: Discussion on the application of the Islamic Legal Maxims in advertising supplementary food product: practices of manufacturers

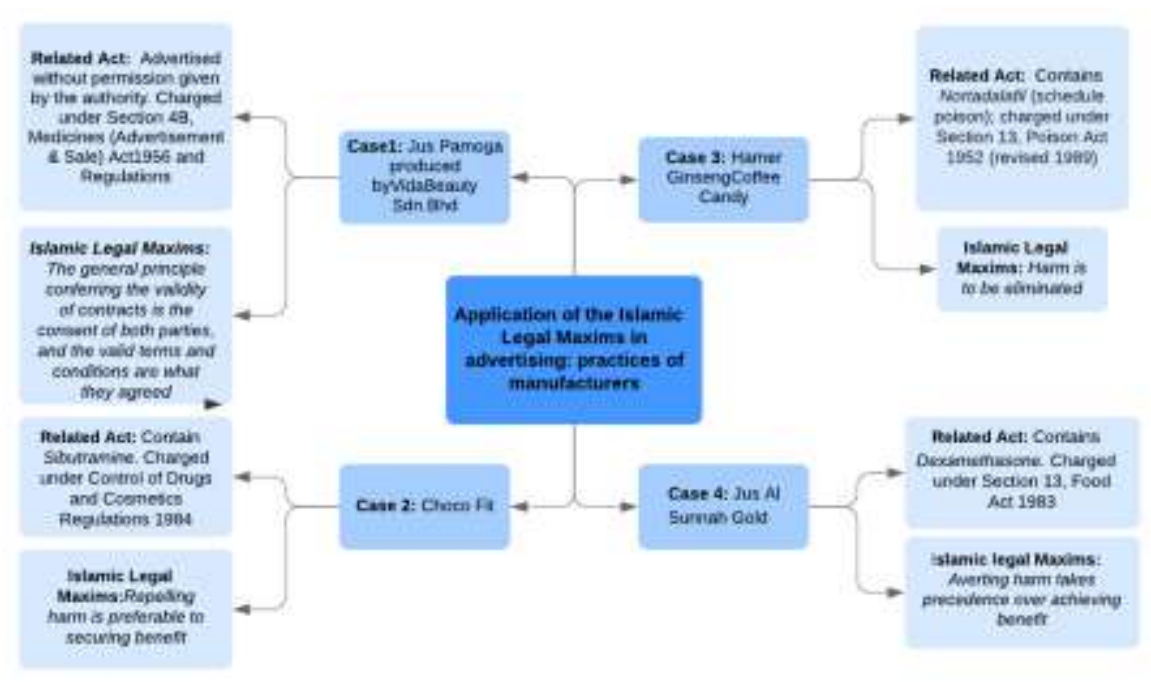

Source: Researcher, 2019

\subsection{The shariah-compliant parameters for manufacturers in advertising based on the integration of Islamic Legal Maxims and shariah.}

The Islamic advertising principle offers a solution for both producers and consumers - theoretically so far. The concept of Islamic advertising is no different from the general concept of advertising (Kesuma, Teuku. 2016). The only difference between them is the implementation of Islamic principles. Particularly, Islam is designed to ensure the trade business is carried out according to Islamic law by preventing the bad elements that give a negative impact on the people. Islam authorizes shariah-compliant business and enumerates the key elements in advertising dimensions such as honesty, do not mix prohibit goods, false description, and more (Abdullah et.al, 2019). Thus, the concept of advertising in the ancient era was performed based on Islamic principles that Allah mentions in the Quran and supported by hadith. There are general guidelines in the Holy Quran and the Sunnah as to how the Islamic mode of advertising should be. All parameters have been summarized in Table 4 below:

Table 4: The shariah-compliant parameters for manufacturers in advertising supplementary food products

\begin{tabular}{|l|l|l|}
\hline No & \multicolumn{1}{|c|}{ Parameters of shariah } & \multicolumn{1}{c|}{ Evidence } \\
\hline 1 & Accuracy & al-Nisa:29; al-A'nam: 143 \\
\hline 2 & Unbiased comparison & al-Ahzab:70; al-Baqarah: 42 \\
\hline 3 & Useful Content & al-Nahl:91; an-Nur: 15, Sunan Abi Dawud 4815 \\
\hline 4 & Assurance & Sunan al-Nasa'i, Hadith 4457 \\
\hline 5 & Allegation value & al-Hujurat:6 \\
\hline 6 & Verification $\quad$ al-Hajj:30; Tirmidhi 1211, Adab al-Kasb wa-al-Ma'sah \\
\hline 7 & Misuse \&child & al-Israa:32; an-Nur: 30-31, al-Azhab:59, al-Kasb \\
\hline 8 & Just & al-Isra:35; al-Takathur: 1-2, Sunan Abi Dawud 4983, Ihya' Ulum al-Din \\
\hline 9 & Liable & al-Nisa: 58 \\
\hline 10 & Compliance & al-Saf:10-11 \\
\hline
\end{tabular}

Shariah's advertising parameters are a step in incorporating religious issues and a business strategy to help advertisers set Islamic marketing targets and measure the effectiveness of ads. First, accuracy and truthfulness. From the Surah al-Nisa verse 29, Allah SWT has clearly stated that: "O you who have believed, do not wrongly consume one another's wealth, but only [in lawful] business by mutual consent. And do not kill yourself [or one another]. Indeed, Allah is ever Merciful to you". Islam requires all parties involved in a business transaction to preserve the facts, state the facts, and stop manipulating the public. According to Shafiq, Haque, \& Abdullah, (2016), the advertising objective is a specific statement on the planned advertising execution in terms of what that advertisement is intended to achieve. Next, a non-biased comparison. It can be seen in the Surah al-Ahzab verse 70: "O you who have believed, fear Allah and speak the words of proper righteousness". It can be understood that advertising must be careful when comparing it with rivals or other goods and services, whether directly or vice versa.

Then, useful content. Allah mentioned in the Surah al-Nahl verse 91: "And fulfil the covenant of Allah when you have taken it". The evidence of content owned by the advertising agency must be supported before claims or promises are made (Mokhtar. A, 2018). 
Moreover, according to hadith, it was related to the principle of assurance and guarantee. Narrated by Hakim bin Hizam, he said: "The Messenger of Allah said: "The two parties to the transaction have the choice as long as they are not separate. If they are honest and open, their transaction will be blessed, but if they tell lies and hide anything, the blessing of their transaction will be lost", (al-Nasa'l, 1986, Sunan an-Nasa'i: No Hadith: 4457). It could be noted that the ads should provide assurance and should be clearly stated with sufficient information in addition to the full text that can be viewed before purchase (Razzaque, 2016). Next, the claim value. Ads should not make false or misleading claims such as (last stock), which do not give rise to a real situation (Fam \& Waller, 2002). Based on Surah al-Hujurat, verse 6: Allah SWT says: "O you who have believed that if a disobedient person comes to you with information, investigate, lest you harm a people out of ignorance and become regrefful about what you have done."

Subsequently, verification by the customer is a necessity. According to the surah al-Hajj verse 30: "avoid false statements". It can be understood that ads involving the user's testimony must be limited to genuinely grateful for the expression of thought, belief, or experience (Fayyad, 2018a). The following parameters are ads that are strictly not misused by women and children. Advertising must avoid children, women, senior citizens, and disadvantaged people (Karim, Ayunni \& Rahman, Noor \& Ramli, Mohd Anuar, 2018). Islam encourages every human being to stand up for justice and fairness in every human act. Also, the advertiser should be responsible and responsive. According to Surah al-Nisa: 58, Allah says: "For Allah commands you to give trust to whom it is due, and to judge between people to judge with justice. Excellent is what Allah has instructed you. Verily, Allah is ever Hearing and Seeing". From the verse, it can be noted that ads must demonstrate a commitment to the consumer alongside the objective of improving the socio-economic well-being of the community, despite their intention to focus on corporate profits without the responsibility of the company (Akhter, Abassi, \& Umar, 2011). Compliance with authority and religion, finally. 10-11, Allah says: "O you who have believed, shall I guide you to a transaction that will save you from a painful punishment? You believe in Allah and His Messenger and strive for the cause of Allah with your wealth and your life. It is best for you if you're supposed to know". The implementation of advertising must comply with the law, either in the form of ethics, policies, or certificates prescribed by the government concerning the use and enjoyment of the public (Azhar Rosly, S., 2010).

\subsection{Conclusion}

Muslims derive their ethical standards from religion, as defined in the Quran and practised by Prophet Muhammad (PBUH) as such; "The wisdom of satisfying the needs of customers through the lawful products and services with the mutual consent "of both seller and buyer to achieve material and spiritual well-being in the world here and hereafter and make consumers aware of it through the good conduct of marketers and shariah-compliant advertising". The above discussion provides cases, acts, Islamic legal maxims that govern the rules of advertising supplementary food products. It is hoped to encourage advertisers of food supplementary products to incorporate proposed Islamic ethics for manufacturers in advertising supplementary food products based on the Islamic Legal Maxim and parameters of shariah. The proposed ethics emphasized the followings:

1) Mutual consent of both parties involved in the advertising.

2) Prioritize to repel harm than preserve the maslahah.Prevention of harm.

3) Uphold the Islamic ethics for advertising as prescribed in al-Quran which is accuracy, non-bias, beneficial content, assurance, no exploitation to women, etc.

The advertisement plays a vital role in display the message. Meanwhile, Islamic Legal Maxims are a significant instrument of Islamic law. Both functions have the power of accountability on issues of food supplementary products in mapping problem and find a solution.

\section{Acknowledgements}

This article is a part of FRGS research grant (FRGS/1/2019/SSI03/UITM/03/6) for the project title "Pembinaan Garis Panduan Patuh Syariah Dalam Pengiklanan Berdasarkan Kaedah Fiqhiyyah"

\section{References}

Abdullah, Kalthom \& Haque, Ahasanul \& Ahmed, Faruk \& Shafiq, Ali. (2019). Towards Devising Islamic Advertising Theory. 10.1007/978-981-13-2677-6_11.

Abdullah. I. (2002) Advertising in Malaysia. In: Kloss I. (eds), More Advertising Worldwide. Springer, Berlin, Heidelberg.

Adi Setia, The Book of Earning a Livelihood (Kitab al-Kasb) by al-Imam Muhammad Ibn al-Hasan al-Shaybani, Kuala Lumpur: IBFIM, 2011.

Advertising Standards Authority Malaysia (ASA), Malaysia code advertising practices, 2008.

Ahmad, A. A., \& Suhardi, S. S. (2018). Parameter Syariah Dalam Produk Berstruktur Islam, 3.

Akbar, F., \& Safira, A. (2017). Investigating Islamic advertising ethics : Perceptions of Indonesian Muslims, 5(2), 43-57.

Akhter, W., Abassi, A. S., \& Umar, S. (2011). Ethical Issue in Advertising in Pakistan: An Islamic Perspective, 13(3), 444-452.

Albaqme, A. S. (2018). Consumer Protection under Saudi Arabia Law: Aidh Sultan Albaqme Stable, https://www.jstor.org/stable/43294662. 
al-Ghazali (1413), al-Mustafa, ed. Muhammad 'Abd al-Salam 'Abd al-Shafi, Beirut: Dar al-Kutub al-IImiyyah.

al-Nasa'i, Ahamd ibn Shu'ayb. (1986). Sunan al-Nasa'i al- Mujtaba, ed. 'Abd al-Fattah Abu Ghuddah (2nd edn.). Allepo: Maktab al-Matbu'at al-Islamiyyah.

al-Qarafi, Shihab al-Din Ahmad. (n.d), Anwar al-Buruq fi Anwa' al-Furuq. Beirut: 'Alam al-Kutub.

Al-Subki, Taj al-Din Abd al-Wahab Ibn al-Taqi al-Din (1991), al-Ashbah wa al-Nazair, Beirut: Dar al-Kutb al-IImiyyah.

al-Suyuti, Jalal al-Din 'Abd Rahman ibn Abi Bakr ibn Muhammad. (1983). Al-Asbah wa al-Naza'ir fi Furu' Fiqh al-Shafi'iyyah, Beirut: Dar al-Kutub al-'Ilmiyyah.

al-Zarqa, Ahmad ibn Muhammad. (2001). Sharh al-Qawaid al-Fiqhiyyah, Damascus, Dar al-Qalam.

al-Zuhayli, Muhammad Mustafa. (2006). al-Qawaid al- Fiqhiyyah wa Tatbiqatuha fi al-Madhahib al-Arba'ah, Damascus: Dar al-Fikr.

Amira, A., Rahman, A., \& Daimin, G. (2018). Rhetoric for Healthy Lifestyle Awareness Campaign on Facebook, 22(December), 1-7.

Andreas Totu \& Halina Sendera Mohd Yakin. 2016. Pengiklanan dan Kanak-Kanak. Sabah: Penerbit Universiti Malaysia Sabah.

Andrews, J. C. 1989. The dimensionality of beliefs toward advertising in general. Journal Advertising 18(1): $26-35$

Ardhityo, R. (2019). Pembangunan Media Pengiklanan Pintar Dengan Menerapkan System Interaction Ads Menggunakan Internet of Things (Doctoral dissertation Universitas Komputer Indonesia).

Azhar Rosly, S. (2010), "Shariah parameters reconsidered", International Journal of Islamic and Middle Eastern Finance and Management, Vol. 3 No. 2, pp. 132146. https://doi.org/10.1108/17538391011054372.

Aziz, Azmin \& Md Rahin, Nurliana \& Asri, Norhazwani. (2019). Halal Advertising on Facebook: A Case Study of Health and Beauty Products in Malaysia. 10.1007/978-3030-10907-3_16.

AzI-UI-Karim, Revival of religious learning (Kitab Ihya' Ulum al-Din) First edition by Imam Ghazali, Pakistan: Darul- Ishat.

Bahagian Regulatori Farmasi. (2018). Laporan Tahunan NPRA 2018.

BRFN (2018), Kenyataan Akhbar KPK 24 September 2018 - Larangan Jualan Produk Jus Al Sunnah, Jus Al Sunnah Gold dan Jus Penawar Keluaran Sri Saga Marketing S/B, diakses pada 1 Disember 2019 dari, https://kpkesihatan.com/2018/09/24/kenyataan-akhbar-kpk-24-september-2018-larangan-jualan-produk-jus-al-sunnah-jus-alsunnah-gold-dan-jus-penawar-keluaran-sri-saga-marketing-s-b/.

Busen, S. M. S., \& Mustaffa, C. S. (2014). The Role of Interactive Advertisements in Developing Consumer- based Brand Equity: A Conceptual Discourse. ProcediaSocial and Behavioral Sciences, 155(October), 98- 103. https://doi.org/10.1016/j.sbspro.2014.10.263

Choco Fit, https://www.facebook.com/Choco-Fit-Pasti-Kurus-729349087466524/.

Choco fit: https://www.bharian.com.my/berita/nasional/2019/06/57 8558/4-produk-dicampur-racun-berjadual

Drug Control Authority (DCA) (NPRA, 2021), https://www.npra.gov.my/index.php/en/about/drug-control-authority-dca/about-the-dca.

Dusuki, Asyraf Wajdi and Abdullah, Nurdianawati Irwani (2007) Maqasid al-shari'ah, maslahah and corporate social responsibility. The American Journal of Islamic Social Sciences (AJISS), 24 (1). pp. 25-45. ISSN 0742-6763.

Ertemel, Adnan Veysel and Ammoura, Ahmad, The Role of Social Media Advertising in Consumer Buying Behavior (March 12, 2019). International Journal of Commerce and Finance, Vol. 2, Issue 1, 2016, 81-89, Available at SSRN: https://ssrn.com/abstract=3350965.

Etemad, K., Ebrahimi, P., Azimi, H., Lotfi, M., \& Nojomi, M. (2016). A content analysis of health-related advertisements in Islamic Republic of Iran broadcasting (IRIB). Medical Journal of the Islamic Republic of Iran, 30(1).

Fam, K. S., \& Waller, D. S. (2002). The influence of religion on attitudes towards the advertising of controversial products, $\quad 38(5), \quad 537-555 .$,

Faris, N. (1939). The Ihya' 'Ulum al-Din of al-Ghazali. Proceedings of the American Philosophical Society, 81(1), 15-19. Retrieved February 15, 2021, from http://www.jstor.org/stable/984962.

Farah Marshita Abdul Patah (2017), Datuk Seri Vida didenda RM4,800, Berita Harian, https://www.bharian.com.my/berita/kes/2017/08/318640/datuk-seri-vida-didendarm4800.

Fayyad, M. (2018a). Measures of the Principle of Good Faith in European Consumer Protection and Islamic Law, a Comparative Analysis, 28(3), 205-230. https://doi.org/10.1163/15730255-

Fayyad, M. (2018b). Misleading Advertising Practices in Consumer Transactions: Can Arab Lawmakers Gain an Advantage from European Insight? https://www.jstor.org/stable/23235574

FDA (The Food and Drug Administration), https://www.fda.gov/food/dietary-supplements. 
Garis Panduan kepada Industri dalam Pengiklanan Produk Kesihatan, NPRA, https://www.pharmacy.gov.my/v2/ms/dokumen/panduan-industri-dalam-pengiklananproduk-kesihatan.html.

Hamer Ginseng coffee and candy, https://www.facebook.com/hamertalk.

Hamer Ginseng Coffee Candy, https://www.nst.com.my/news/nation/2019/09/519022/tr readers-still-selling-banned-ginseng-candy-ed-drug http://juspamoga.blogspot.com/2015/05/khasiat-delima-dalam-jus-pamoga-vida.html.

Hassali, Mohamed \& Shakeel, Sadia. (2020). Pharmaceutical and Cosmeceutical Marketing and Advertising in Malaysia: An Overview of Current Governing Laws and Regulations. 10.26717/BJSTR.2020.26.004357.

Huang, Liyan \& Mehta, Kaye \& Wong, Mun. (2011). Television food advertising in Singapore: The nature and extent of childrens exposure. Health promotion international. 27. 187-96. 10.1093/heapro/dar021.

Ibn al-Subki, 'Ali ibn 'Abd al-Kafi. (1995). Al-Ibhaj Sharh al-Minahj. Beirut: Dar al-Kutub al- 'Ilmiyyah.

Ibn Majah, Muhammad ibn Yazid. (1998). Sunan Ibn Majah, ed. Muhammad Fua'ad 'Abd al-Baqi, Beirut: Dar al-Fikr.

Ibn Rajab, 'Abd al-Raḥmān ibn Aḥmad. (n.d.). Al-Qawā id. Beirut: Dār al-Kutub al 'Ilmiyyah, Beirut: Dar al-Kutub al-IImiyyah.

Ilah Hafiz Aziz (2019) 4 produk dicampur racun berjadual, Accessed from, https://www.bharian.com.my/berita/nasional/2019/06/578558/4-produk-dicampur-racunberjadual.

Jus al-Sunnah Gold: http://www.astroawani.com/berita- malaysia/awas-jus-al-sunnah-jus-al-sunnah-gold-dan- jus-penawar-boleh-bawa-maut-186512

Jus pamoga: https://www.mynewshub.tv/utama-sensasi/dsv- kena-denda-serik-nak-bersiaran-live-lagi/

KpKesihatan (2019) Kenyataan Akhbar KPK 5 September 2019 - Hamer Ginseng \& Coffee Candy yang Dicampurpalsu Racun Berjadual "Nortadalafil", https://kpkesihatan.com/2019/09/05/kenyataan-akhbar-kpk-5-september-2019-hamer-ginseng-coffee-candy-yang-dicampurpalsu-racun-berjadual-nortadalafil/

Kamali, M.H. (2012) Shari'ah Law, An Introduction, Oxford: Oneworld.

Kamassi, A., Abdul Manaf, N.H. and Omar, A. (2020), "The need of international Islamic standards for medical tourism providers: a Malaysian experience", Journal of Islamic Marketing, Vol. 12 No. 1, pp. 113-123.

Karim, Ayunni \& Rahman, Noor \& Ramli, Mohd Anuar. (2018). Women's Involvement As A Subject of Advertising From Islamic Ruling Perspective. 10.15364/ris20180502-01.

Kesuma TM (2012), Prinsip dan Kriteria Periklanan menurut Perspektif Islam, Jurnal Ekonomi dan Kewangan Islam, Jilid 1, No 1.

Koorosh Etemad, Ebrahimi, P., Azimi, H., Lotfi, M., \& Nojomi, M. (2016). A content analysis of health-related advertisements in the Islamic Republic of Iran Broadcasting (IRIB). Medical Journal of the Islamic Republic of Iran, 30(1).

Laldin, Mohamad Aklam et.al .2020. Islamic Legal Maxims \& Their Application in Islamic Finance. Kuala Lumpur: ISRA.

Lembaga Iklan Ubat 1976, https://www.pharmacy.gov.my/v2/sites/default/files/document-upload/medicine-advertisements-board-regulations-1976_1.pdf. Malaysian Computer and Multimedia Industry Association (PIKOM), E-commerce in Malaysia, (https://datareportal.com/)

Marhaeni, D. (2020). Iklan Anak Produk Makanan Dan Minuman Di Televisi Dan Etika Media Dalam Perspektif Kearifan Lokal. Jurnal IImiah Komunikasi Makna, 3(1), 5062 .

Medical Advisory Board (MAB), https://www.pharmacy.gov.my/v2/en/content/medicine-advertisements-board.html.

Meyer, S. B., Shnir, F., Simeonov, S., Kozek, E., O'malley, C., \& Jaye, D. (2016). U.S. Patent No. 9,361,631. Washington, DC: U.S. Patent and Trademark Office.

MOF, Ekonomi Digital, https://belanjawan2021.treasury.gov.my/index.php/ms/

Mohamad Yunus, Mohamad Ismail. (2019). The Position and Application of Islamic Legal Maxims (Qawaaid al-Fiqhiyyah) in the Law of Evidence (Turuq al-Hukmiyyah). FIAT JUSTISIA. 13. 10.25041/fiatjustisia.v13no1.1479.

Mokhtar, A. (2018). A framework for Islamic advertising: Using Lavidge and Steiner "s hierarchy of effects model, (January 2016).

Mokhtar, A. (2019). Empowerment through Advertisements: The Socially Responsible Role of Depicting Images of Special Needs for Normalcy. International Journal for Studies on Children, Women, Elderly and Disabled People, d (January), 86-94.

Mokhtar, A. (2019). The advertising practitioner and the imbuement of Al-Ghazali's Islamic ethics framework. In Forum Komunikasi (Vol. 14, No. 1, pp. 1-22). Faculty of Communication and Media Studies, Universiti Teknologi MARA.

Nanda, A. A. G. S., \& Sukranatha, A. A. K. (2019). Perlindungan Hukum Terhadap Konsumen Yang Dirugikan Akibat Iklan Makanan Tidak Sesuai Dengan Kondisi Barang Yang Diperdagangkan. Kertha Semaya: Journal IImu Hukum, 6(11), 1-14.

Nor Afzan Mohamad Yusof (2019) Pengeluar makanan dilarang dakwa produk 'menyihatkan'. Access through,

https://www.bharian.com.my/berita/nasional/2019/01/521605/pengeluar-makanan-dilarang-dakwa-produk-menyihatkan

O'Donoghue AC, Sullivan HW, Williams PA, Squire C, Betts KR, Fitts Willoughby J, Parvanta S. (2016), Consumers' Understanding of FDA approval requirements and 
composite scores in direct-to-consumer prescription drug print ads. J Health Commun.21(8):927-34.

PWC, Advertising Innovation, https://www.pwc.com/my/en.html

Rahim, M. H. A. (1996). Perkembangan industri pengiklanan di Malaysia (UKM, 1996).pdf.

Rahim, M. H. A. (2009). Pengiklanan Islami: Penjanaan konsep dan pelaksanaan. Jurnal Melayu, 4(4), 59-72.

Rahman, Md. Habibur. (2015). Islamic Legal Maxims and their Relevance to Business and Finance. Journal of Islam in South Asia (JISA). 1. 205-232.

Rasit, Rosmawati Mohamad, Salasiah Hanin Hamjah, Azimah Misrom, and Nur Hikmah Yahya. "Socio-Cultural Discourse of Muslim Society in Social Semiotics Aspect of Advertising Text in Malaysia". Humanities \& Social Sciences Reviews 7, no. 5 (September 28, 2019): 256-263. Accessed February 15, 2021. https://giapjournals.com/hssr/article/view/hssr.2019.7531.

Razzaque, M. A. (2016). Advertisement in the Muslim World: A Critical Analysis from the Islamic Perspective, II (1), 100-108.

Safira, Anya (2017) Investigating Islamic advertising ethics: Perceptions of Indonesian Muslims. Journal of Emerging Economies and Islamic Research (JEEIR), 5 (2). pp. 1-15. ISSN $2289-2559$

Serimah Mohd Sallehuddin, 2020), Karya, taraf global, https://www.bharian.com.my/hiburan/selebriti/2021/01/773349/karya-taraf-global

Shafiq, A. (2018). A collection of Islamic advertising principles: revisited and detailed. International Journal of Islamic Marketing and Branding, 3(3), 209. https://doi.org/10.1504/ijimb.2018.10016950

Shafiq, A., Haque, A., \& Abdullah, K. (2016). A Collection of Islamic Advertising Principles,

https://www.researchgate.net/publication/309490921_A_Collection_of_Islamic_Advertising_Principles.

Sunan Abi Dawud 4983, Book 42, Hadith 4965

The Adverse Drug Reaction Report 2014-2019, National Pharmaceutical Regulatory Agency, MOH (2019),

https://www.npra.gov.my/index.php/en/informationen/annual-reports/national-centre-for-adverse-drug-reaction-monitoring-annual-report.

The Communications and Multimedia Act 1998, https://www.mcmc.gov.my/en/legal/acts.

The Food Act 1983, http://www.agc.gov.my/agcportal/uploads/files/Publications/LOM/EN/Act\%20281.pdf.

The Poisoning Act 1952, https://www.pharmacy.gov.my/v2/en/documents/poisons-act-1952-and-regulations.html.

The Trade Description Act 2011, https://www.wipo.int/edocs/lexdocs/laws/en/my/my068en.pdf. Medicines (Advertisement \& Sale) Act 1956 and Regulations, https://www.pharmacy.gov.my/v2/en/documents/medicines-advertisement-sale-act-1956-and-regulations.html.

Ullah, Najeeb \& Hussain, Mustansar. (2015). Impact of Unethical Advertising, Misleading Information or Deceptive Advertising on Customer Purchasing Intention with Mediating Effect of Word of Mouth: Case of Pakistan. International Journal of Innovation and Economic Development. 1. 49-69. 10.18775/ijied.1849-75517020.2015.14.2005

Yarar, Ali. (2020). Halal Advertising on YouTube: A Case Study of Fast-Food Brands in Malaysia. Food Research. 4. 157-163. 10.26656/fr.2017.4(S1). S34. 